\title{
STUDIES ON THE PREVENTION OF RHEUMATIC FEVER: THE EFFECT OF TIME OF INITIATION OF TREATMENT OF STREPTOCOCCAL INFECTIONS ON THE IMMUNE RESPONSE OF THE HOST ${ }^{1}$
}

\author{
By LORING L. BROCK 2 AND ALAN C. SIEGEL 3 \\ (From the Streptococcal Disease Laboratory, Francis E. Warren Air Force Base, Wyoming, and \\ the Department of Preventive Medicine, School of Medicine, Western Reserve \\ University, Cleveland, Ohio)
}

(Submitted for publication February 23, 1953; accepted March 18, 1953)

Previous studies have established the fact that penicillin treatment of acute streptococcal pharyngitis results in a marked suppression of antibody formation $(1,2,3)$. This is in contrast to the failure of penicillin treatment to alter the immune response in patients with pneumococcal pneumonia (4). It has been suggested that in the latter case, sufficient pneumococcal antigen is formed during the early phases of pneumonia to provide a maximal antigenic challenge before penicillin therapy is instituted (4). The capacity of penicillin to suppress the production of streptococcal antibodies suggests that in streptococcal infections the antigenic challenge may be presented more gradually. Under such circumstances, it would be expected that the effectiveness of penicillin in this regard would be related to the time of institution of therapy. Since no definitive information on this point has hitherto been obtained, the present study was designed to test this hypothesis.

\section{DESCRIPTION OF STUDY}

All patients fulfilling the following criteria were included in the study: the presence of exudative pharyngitis, history of onset of symptoms less than 31 hours before admission, and subsequent isolation of group $A$ streptococci from the initial throat culture. Patients with a past history of rheumatic fever or chorea were excluded. A throat culture and a serum specimen were obtained on each patient at the time of admission and on the fourteenth, twenty-first and twenty-eighth days from the onset of symptoms.

1 This investigation was conducted under the sponsorship of the Commission on Acute Respiratory Diseases and the Commission on Streptococcal Diseases, Armed Forces Epidemiological Board, and was supported by the Offices of The Surgeons General, Departments of the Army and Air Force, Washington, D.C.

2 Capt., MC, USAF.

3 Capt., MC, USAR.
Bacteriological and serological studies were performed by methods previously described $(5,6,7)$. Antistreptolysin "O" titers were determined on all sera from each patient in a single test, and all tests were performed with the same lot of streptolysin and read by the same observer.

\section{RESULTS}

Each of the 349 patients studied was assigned to one of four treatment groups according to a random sequence previously determined by a shuffled deck of cards. Table I indicates the distribution of the patients among four treatment groups according to the time of initiation of therapy and the amounts of penicillin employed. The groups were essentially comparable, as shown in Table II, with respect to the admission leukocyte count, predominance of group A streptococci on initial throat culture, history of sore throat within the previous four weeks, and initial antistreptolysin titer. There was some variation in the distribution of serological types of infecting streptococci in the four treatment groups, and analysis revealed only slight differences in the antistreptolysin responses to infection with the different types.

Table III shows the average increase in antibody in each group. Early treatment with penicillin was followed by a much smaller average antibody rise than that found in the control group. In those groups of patients in which treatment was delayed for three or five days, there was progressively less suppression of antibody response. Nevertheless, considerable reduction in antibody response was obtained even when treatment was delayed for five days.

Figure 1 shows the per cent of patients in each group who developed an antibody rise of 200 units or over. It can be seen that twice as many patients developed this response when treatment was de- 
TABLE I

Distribution of cases according to treatment groups

\begin{tabular}{lccc}
\hline \multicolumn{1}{c}{ Group } & $\begin{array}{c}\text { Number } \\
\text { of cases }\end{array}$ & $\begin{array}{c}\text { Time of initial } \\
\text { injection* }\end{array}$ & \multicolumn{1}{c}{ Therapy } \\
\hline $\begin{array}{l}\text { Immediate } \\
\text { treatment }\end{array}$ & 86 & $22-31$ hours & $\begin{array}{l}\text { Three injections } \\
\text { of } 600,000 \text { units } \\
\text { of penicillint at } \\
3 \text { day intervals }\end{array}$ \\
$\begin{array}{l}3 \text { day delay } \\
\text { in treatment }\end{array}$ & 89 & $70-79$ hours & day delay \\
$\begin{array}{l}5 \text { din treatment } \\
\text { Control }\end{array}$ & 87 & $118-127$ hours & $\begin{array}{l}\text { Saline placebos } \\
\text { given on first and } \\
\text { ifth hospital day }\end{array}$ \\
\hline
\end{tabular}

* Time from onset of symptoms.

† Procaine penicillin $G$ in sesame oil, with 2 per cent aluminum monostearate.

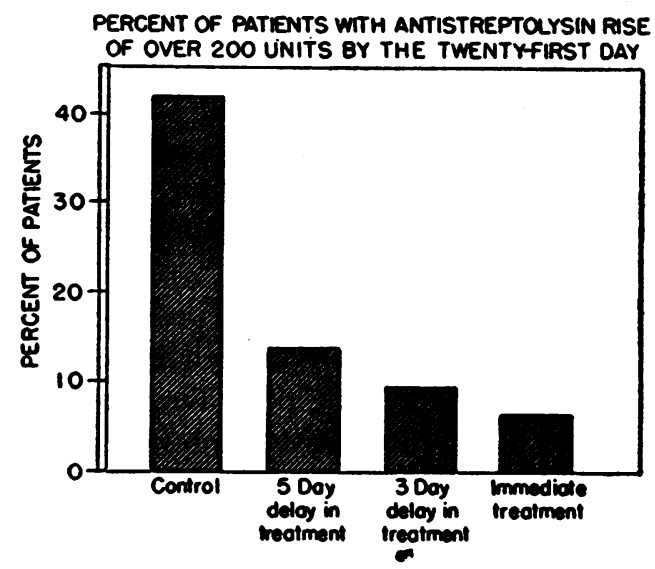

Fig. 1

TABLE II

Comparability of the treatment groups

\begin{tabular}{|c|c|c|c|c|}
\hline & \multicolumn{4}{|c|}{ Number of patients in treatment groups } \\
\hline & $\begin{array}{l}\text { Immediate } \\
\text { treatment } \\
(80)\end{array}$ & $\begin{array}{l}3 \text { day delay } \\
\text { ix treatment } \\
\text { (89) }\end{array}$ & $\begin{array}{l}5 \text { day delay } \\
\text { in treatment } \\
\text { (87) }\end{array}$ & $c_{(87)}^{\text {Conutrol }}$ \\
\hline $\begin{array}{l}\text { Admission leucocyte } \\
\text { count } 12,000 \text { and over }\end{array}$ & 64 & 63 & 65 & 69 \\
\hline $\begin{array}{l}\text { Initial antistreptolysin } \\
\text { titer } 125 \text { units and under }\end{array}$ & 56 & 66 & 64 & 65 \\
\hline $\begin{array}{l}\text { History of sore throat } \\
\text { within previous } 4 \text { weeks }\end{array}$ & 8 & 12 & 7 & 11 \\
\hline $\begin{array}{l}\text { Group A streptococci } \\
\text { predominant* growth } \\
\text { on initial culture }\end{array}$ & 81 & 79 & 76 & 81 \\
\hline $\begin{array}{lr} & 14 \\
\text { Type of group A } & 30 \\
\text { streptococci from } & 3 \\
\text { initial throat culture } & 18 \\
& 6\end{array}$ & $\begin{array}{r}10 \\
19 \\
9 \\
15 \\
8 \\
\quad 10\end{array}$ & $\begin{array}{r}14 \\
26 \\
6 \\
14 \\
9 \\
9\end{array}$ & $\begin{array}{r}20 \\
23 \\
4 \\
13 \\
8 \\
10\end{array}$ & $\begin{array}{r}20 \\
28 \\
2 \\
13 \\
6 \\
7\end{array}$ \\
\hline Others & 15 & 11 & 9 & 11 \\
\hline
\end{tabular}

* Over 50 colonies on plate.

TABLE III

Average antistreptolysin response in relation to time of initiation of penicillin therapy

\begin{tabular}{|c|c|c|c|c|c|c|c|c|c|c|c|}
\hline \multirow[b]{3}{*}{$\begin{array}{c}\text { Treatment } \\
\text { groups }\end{array}$} & \multirow[b]{3}{*}{$\begin{array}{l}\text { Number } \\
\text { of cases }\end{array}$} & \multicolumn{10}{|c|}{ Antistreptolysin "O" titers } \\
\hline & & \multicolumn{4}{|c|}{ Average units } & \multicolumn{3}{|c|}{ Average units rise } & \multicolumn{3}{|c|}{$\begin{array}{l}\text { Per cent inhibition as } \\
\text { compared to controls }\end{array}$} \\
\hline & & Initial & $\begin{array}{l}14 \\
\text { day }\end{array}$ & $\begin{array}{l}21 \\
d a y\end{array}$ & $\begin{array}{c}28 \\
d a y\end{array}$ & $\begin{array}{l}14 \\
\text { day }\end{array}$ & $\begin{array}{l}21 \\
d a y\end{array}$ & $\begin{array}{l}28 \\
\text { day }\end{array}$ & $\begin{array}{l}14 \\
d a y\end{array}$ & $\begin{array}{c}21 \\
d a y\end{array}$ & $\begin{array}{c}28 \\
d a y\end{array}$ \\
\hline $\begin{array}{l}\text { Immediate } \\
\text { treatment }\end{array}$ & 86 & 137 & 214 & 224 & 231 & 77 & 87 & 94 & 58.4 & 60.3 & 56.0 \\
\hline $\begin{array}{l}3 \text { day delay } \\
\text { in treatment }\end{array}$ & 89 & 121 & 205 & 229 & 235 & 84 & 108 & 114 & 55.0 & 50.3 & 46.8 \\
\hline $\begin{array}{l}5 \text { day delay } \\
\text { in treatment }\end{array}$ & 87 & 120 & 222 & 251 & 246 & 103 & 131 & 126 & 44.8 & 40.0 & 41.1 \\
\hline Control & 87 & 119 & 304 & 337 & 333 & 186 & 218 & 214 & - & - & - \\
\hline
\end{tabular}


layed five days, compared to the group who received immediate therapy.

In this study one case of rheumatic fever occurred in the control group. This patient showed a 375 unit antistreptolysin rise by the fourteenth and twenty-first days, and a 750 unit rise by the twenty-eighth day.

Reinfections and recurrences of positive cultures at follow-up examination remained under 13 per cent in all groups receiving penicillin, and did not appreciably alter the antistreptolysin responses of any group.

\section{DISCUSSION}

These data indicate that there is a correlation between the time of institution of penicillin therapy and the degree of suppression of antistreptolysin formation : the earlier the treatment the greater the suppression. Therapy, begun not later than 31 hours after the onset of symptoms of streptococcal pharyngitis, effectively reduces the subsequent antistreptolysin response at 21 days by approximately 60 per cent, while therapy begun five days after the onset of symptoms results in a 40 per cent suppression. These observations support the hypothesis that the antigenic challenge during acute streptococcal pharyngitis occurs gradually, over a period of several days, and that an appreciable percentage of the total immune response develops as a result of antigen formed after the fifth day of disease.

It is difficult to relate these data to the overall problem of the prevention of rheumatic fever, since the present study was too limited to yield any direct evidence as to the effectiveness of delayed penicillin therapy in reducing the attack rate for this complication. It has been shown that there is a correlation between high convalescent antibody titers following streptococcal infections and the development of rheumatic fever (8). It would thus seem that early therapy of streptococcal infections would be advisable; delayed therapy, however, might exert some effect on the incidence of rheumatic fever. It is hoped that studies now in progress will provide information on this point.

\section{CONCLUSIONS}

Early treatment of streptococcal pharyngitis with penicillin is more effective than delayed ther- apy in suppression of antistreptolysin formation. Treatment instituted as late as five days from onset of symptoms of pharyngitis results in significant antibody suppression.

\section{ACKNOWLEDGMENTS}

The authors wish to express their appreciation to Captain Harold I. Griffeath and Captain Robert S. Fontana of the medical service for their assistance and cooperation.

Members of the staff of the Streptococcal Disease Laboratory who assisted in these studies include Dr. Charles H. Rammelkamp, Director, Captain Lewis W. Wannamaker and Captain Chandler A. Stetson, Assistant Directors, and Major Edward O. Hahn, Major Harold B. Houser, Captain William D. Perry, Captain Bertrand L. Stolzer, and T/Sgt William H. Stroud.

\section{REFERENCES}

1. Weinstein, L., and Tsao, C. C. L., Effect of types of treatment on development of antistreptolysin in patients with scarlet fever. Proc. Soc. Exper. Biol. \& Med., 1946, 63, 449.

2. Anderson, H. C., Kunkel, H. G., and McCarty, M., Quantitative antistreptokinase studies in patients infected with group A hemolytic streptococci: a comparison with serum antistreptolysin and gamma globulin levels with special reference to the occurrence of rheumatic fever. J. Clin. Invest., 1948, 27, 425.

3. Wannamaker, L. W., Rammelkamp, C. H., Jr., Denny, F. W., Brink, W. R., Houser, H. B., Hahn, E. O., and Dingle, J. H., Prophylaxis of acute rheumatic fever by treatment of the preceding streptococcal infection with various amounts of depot penicillin. Am. J. Med., 1951, 10, 673.

4. Jordan, W. S., Jr., Badger, G. F., and Dingle, J. H., Immunological studies of pneumococcal pneumonia in patients treated with penicillin. J. Clin. Invest., 1950, 29, 161.

5. Wannamaker, L. W., Denny, F. W., Rammelkamp, C. H., Jr., and Brink, W. R., Use of Maxted's method for group classification of hemolytic streptococci. Proc. Soc. Exper. Biol. \& Med., 1950, 73, 467.

6. Swift, H. F., Wilson, A. T., and Lancefield, R. C., Typing group $A$ hemolytic streptococci by $\mathbf{M}$ precipitin reactions in capillary pipettes. J. Exper. Med., 1943, 78, 127.

7. Hodge, B. E., and Swift, H. F., Varying hemolytic and constant combining capacity of streptolysins; influence on testing for antistreptolysins. J. Exper. Med., 1933, 58, 277.

8. Rammelkamp, C. H., Wannamaker, L. W., and Denny, F. W., The epidemiology and prevention of rheumatic fever. Bull. New York Acad. Med., 1952, 28, 321. 